\title{
THE PROBLEM OF DESIGNATING ELEMENTARY TERRAINS FOR THE PURPOSE OF SZCZECIN ALGORITHM OF REAL ESTATE MASS APPRAISAL
}

\author{
Józef Hozer \\ Institute of Econometrics and Statistics \\ University of Szczecin \\ e-mail: jozef.hozer@usz.edu.pl \\ Sebastian Gnat \\ Institute of Econometrics and Statistics \\ University of Szczecin \\ e-mail: sebastian.gnat@usz.edu.pl \\ Sebastian Kokot \\ Institute of Econometrics and Statistics \\ University of Szczecin \\ e-mail:sebastian.kokot@usz.edu.pl \\ Wojciech Kuźmiński \\ Institute of Econometrics and Statistics \\ University of Szczecin \\ e-mail:wojciech.kuzminski@usz.edu.pl
}

\section{Abstract}

One of the key determinants of the quality of real estate mass appraisal is the algorithm used for conducting such an appraisal. Other determinants include detailed methodological and substantive solutions within the scope of a selected, applied algorithm. This article is dedicated to one of the major stages of the process of land real estate mass appraisal with the use of the Szczecin Algorithm of Real Estate Mass Appraisal (SAREMA), namely defining and determining the so-called elementary terrains. The paper aims to present the methods for designating the boundaries of elementary terrains, the manner of defining their number and size and, consequently, the number of real properties that will be covered by an automated process of mass appraisal in a given area.

Ways of defining the boundaries of elementary terrains were proposed in the paper based on the existing surveying districts, zoning plans, background maps, thematic map layers, real estate market analyses as well as statistical methods.

Elementary terrain boundaries thus designated were verified with the use of actual real estate resources of the city of Szczecin.

Key words: mass appraisal, appraisal algorithms, elementary terrains, spatial analyses.

JEL Classification: C51, R30, R39.

Citation: Hozer J., Gnat S., Kokot S., Kuźmiński W., 2019, The Problem of Designating Elementary Terrains for the Purpose of Szczecin Algorithm of Real Estate Mass Appraisal, Real Estate Management and Valuation, vol. 27, no. 3, pp. 42-58.

DOI: 10.2478/remav-2019-0024 


\section{Introduction}

In the practice of real estate appraisal, two entirely different situations may occur in terms of the appraisal process organization:

1. individual appraisal,

2. mass appraisal (JAHANSHIRI, BUYONG, SHARIFF 2011).

An individual appraisal involves a situation in which one real property or a relatively small group of real properties is the subject of an appraisal. Appraised real properties may differ in terms of their location, market type (segment and sub-segment), appraisal purpose and scope, dates of establishing the property condition and its price level, etc. Individual appraisals are the most frequently performed procedures with the use of valuation principles resulting from legal regulations and a series of socalled professional norms, which in Poland comprise of professional, basic and specialist standards of appraisal as well as interpretational notes (e.g. ŹRÓBEK at al. 2000, HOZER ed. 2008).

We deal with mass appraisal when (e.g. HOZER et al. 2002; KURYJ 2007; TELEGA et al. 2002):

1. the subject of an appraisal involves a large number of real properties of one type,

2. appraisal is to be conducted with a uniform approach resulting in cohesive results,

3. all the properties subject to appraisal are valued "at the same time", assuming the same dates for establishing the property conditions and price level.

In terms of organization, mass appraisal is generally conducted in two stages:

1. gathering of all the necessary information and data concerning all the appraised properties and of a relevant market,

2. conducting calculations of the value of all the properties subject to appraisal with the use of a suitable algorithm.

The differences in the organization of the work aiming to determine the value of a group of properties in these two cases may thus be compared to the difference in the finishing of each of several dozen flats in one block of flats by different owners, and the finishing of several hundred hotel rooms in a newly erected chain hotel.

Individual and mass appraisals should not be perceived as mutually alternative or substitutive procedures, but rather as complementary ones. In certain areas, mass appraisal will be quicker and cheaper than an individual one, whereas in other cases this may be quite the opposite. Typical areas in which mass appraisal is deemed to be useful include (HOZER et al. 1999):

- property valuation for the purpose of updating annual perpetual usufruct charges,

- property valuation for the purpose of estimating the economic results of adopting or amending local zoning plans,

- monitoring the values of sets of real properties constituting securities of credit exposures held by a bank in order to calculate LtV for the bank's credit portfolio (CHO, MEGBOLUGBE 1996, KORTEWEG, SORENSEN2016, TZIOUMIS 2017),

- universal real property taxation (BRADBURY, MAYER, CASE 2001).

Both individual as well as mass appraisal must be set suitably high requirements regarding valuation precision, bearing in mind that they can be affected by a variety of factors, also ones directly unrelated to the appraisal method itself (ZHU, PACE 2012). The acceptance of an adopted model of real property mass appraisal ought to be based on the reliability of results, which is intended in particular to prevent complaints, justified from the standpoint of the parties, regarding the manner of appraisal as well as the obtained results themselves. What is more, it ought to also be based on the reliability of the determined cadastral values with a transparent appraisal structure and a relatively low number of distinctly defined and clearly presented real estate characteristics (cf. SAWIŁOW, AKIŃCZA 2011).

\section{Szczecin algorithm of real estate mass appraisal}

The purpose and conditions of mass appraisal indicate that employing algorithm-based procedures for determining property value is justified. When attempting to classify the methods applied in practice or the ones subject to scientific research as a possible method of conducting the process, the following groups of methods need to be differentiated (e.g.: DOSZYŃ 2012; HOZER 2001; KOKOT 2006; KURYJ 2007; PAWLUKOWICZ 2001; PRYSTUPA 2001; TELEGA et al. 2002):

1. methods based on econometric models of multiple regression and their derivatives,

2. methods based on neural networks,

3. introspective methods. 
The problem of this article focuses on one of the methods classed in the third of the above-listed groups. Such methods are based on models specially developed for the purpose of property valuation, which, on the one hand, are capable of accounting for the specificity of local market operation (spatial layout, local fashions, etc.), while on the other hand, cope (within a specified scope) with the imperfections of that market in the form of a relatively low number of transactions far better than the methods specified above. Examples of the methods from that group include the so-called Charge Update System (CUS) developed by Professor J. Czaja and the Szczecin algorithm of real estate mass appraisal developed under the supervision of Professor J. Hozer (HOZER et al. 1999). It is the procedure of the Szczecin algorithm of real estate mass appraisal that raises the issue of designating the so-called elementary terrains, for which, in turn, market value ratios (WWR) are determined based on randomly selected and individually appraised representative real properties.

The Szczecin algorithm of real estate mass appraisal is based on the assumption that a hypothetical property value is a function of its attributes. In a purely theoretical perspective, the value can be calculated in accordance with the following formula (HOzER et al. 1999):

$$
W h_{i}=\operatorname{pow}_{i} \times W_{b a z} \times \prod_{k}\left(1+A_{k i}\right)
$$

$W h_{i} \quad$ - hypothetical value,

pow $w_{i}$ - plot surface,

$w_{b a z} \quad$ - value of $1 \mathrm{~m}^{2}$ of the cheapest land (without the technical infrastructure) in the appraised area,

$A_{k} \quad$ - values assigned to particular property attributes (they are defined on the basis of analyses and diagnoses of the local market and they reflect the strength of the influence of individual attributes on a property value).

Valuation practice demonstrates that thus calculated hypothetical values of real property typically differ significantly from transaction values or the values determined by appraisers. However, they can be used for estimating the degree of differences in market values and the values generated with Formula 1. The relationships of the market values of representative properties to the hypothetical values calculated in each of the isolated elementary terrains yield the so-called market value ratios (WWR) (HOZER et al. 1999):

$$
\widehat{W W R}_{j}=\frac{W r z_{i}}{W h_{i}}
$$

$W r z_{i} \quad$ - market values of representative properties defined by property appraisers.

Subscript " $\mathrm{j}$ " means that calculations are made for elementary terrains, i.e. each elementary terrain will have its own WWR.

In the event when more than a dozen or so properties are located in one elementary terrain, $W W R^{\prime}$ s calculations ought to be based on more than one property. We then obtain $W r z_{i}$ and $W h_{i}$ values through the computation of averages from market and hypothetical values of $1 \mathrm{~m}^{2}$ occurring in a given elementary terrain. In the original version of the algorithm, an arithmetic average was used for that purpose. Since the Szczecin algorithm uses a formula of multipliers, a geometric average seems to be more appropriate, since it is the geometric average that, according to the theory of statistics, is meant to determine an average value level of statistical units expressed in relative numbers attributes of multiplicative type (HOZER 1999 - ed.; KOT, JAKUBOWSKI, SOKOŁOWSKI 2007). Furthermore, it is less sensitive to extreme values than the arithmetic average. Admittedly, it carries a risk of arriving at zero value in the case of a zero value of even one statistical unit; however, once it is used for determining an average value of $W W R_{j}$, such a risk no longer exists. Therefore, in the abovespecified situation the following formula is applied:

$$
\widetilde{W W R_{j}}=\sqrt[n]{\prod_{i=1}^{n} \frac{W r z_{i}}{W h_{i}}}
$$

WWR ratio defines how much higher the value of the appraised $1 \mathrm{~m}^{2}$ of land is in relation to a hypothetical value of $1 \mathrm{~m}^{2}$ of land found in a given elementary terrain, adjusted for those individual attributes that refer to the appraised real property (e.g. technical infrastructure, access to city 
transportation, neighborhood). The WWR ratio puts the generated prices "on a market basis" through the algorithm. It is obvious that $A_{i}$ attributes affect the value of a property. If, however, we use only them as a basis for calculating land value, it would turn out that two plots of the same surface and attributes, or even lying within the same distance from the center, but found in locations different in terms of attractiveness, would have the same value. Thus, the WWR ratio measures the relation between a certain theoretical value of the property calculated on the basis of attributes and the appraisal conducted by the market.

Having a WWR market value ratio for a given elementary terrain we can, in turn, appraise the market value of each land property located in it, taking into account its individual characteristics (its attributes). To that end, we will use the following formula:

$$
W_{i}=W W R_{j} \times p o w_{i} \times W_{b a z} \times \prod_{k}\left(1+A_{k i}\right)
$$

As becomes evident, the application of the formula requires having the same information that was used to calculate the hypothetical values of representative properties and WWR values. Therefore, building suitable data bases becomes essential, including a data base of WWR ratios. The first stage of building a data base of WWR ratios is the designation of elementary terrains. It is worth noting that, in theory, any value can basically be substituted for Wbaz not affecting the results accuracy. However, using $W_{b a z}$ value of $1 \mathrm{~m}^{2}$ of the cheapest land (without technical infrastructure) in the territory where appraisal is carried out, we gain a logical interpretation of algorithm parameters - apart from $W_{b a z}$ itself, also for $W W R_{j}$ and $A_{k}$. In other words, as a certain value needs to be adopted, and among them there is one whose application may bring an additional benefit in the form of a clearer interpretation of all the parameters, precisely that value ought to be adopted. The method of defining it remains a separate research issue, not developed in this article.

It is important that the models employed in appraisal ought to be adapted each time to the individual conditions found in a local market, or even to its segments or, if any exist, - to sub-markets. In the center of multiple studies on the structure and functioning of local markets, there is a conviction that, in order to effectively understand the functioning of a highly complex and spatially heterogeneous system, individual applications to properly isolated sub-markets need to be separated, since it is at those sub-markets that real statistical trends are revealed (KESKIN, WATKINS 2017). The major advantages of such an approach include greater expected predictive accuracy of the models (ADAIR, BERRY, MCGREAL 1996). Moreover, the benefits may involve greater usefulness of the results for decision-makers (GALSTER 1996) and help in improving the process of decision-making by entities operating on the real estate market (inter alia RAE 2015, PALM 1978, PENG, THIBODEAU 2013). Various methods can be selected for isolating sub-markets, such as statistical analyses (BOURASSA, HAMELINK, HOESLI, MACGREGOR 1999), methods using cross-price elasticity (PRYCE 2013), the theory of hedonic prices (ROSEN 1974) or spatial analyses (WU, SHARMA 2012).

\section{The issue of designating elementary terrains}

The issue of the proper designation of elementary terrain must, therefore, be recognized as one of the crucial problems, from the standpoint of the accuracy of obtained appraisal results (HOZER et al. 1999, CELLMER et al. 2011). An elementary terrain is an area in which a certain number of appraised properties are located, exerting, in fact, a similar, and formally the same impact of the location on their value. In other words, all the properties located in a given elementary terrain do not differ in terms of location for the purpose of establishing its impact on the real property value in the algorithm. As becomes apparent, such understanding of an elementary terrain is not equivalent to the concept of a segment, a sub-segment or even sub-market of the real estate market. As mentioned previously, designation of elementary terrains constitutes an important stage of performing a mass appraisal with the use of SAREMA. Not all the methods used for that purpose require the designation of elementary terrains or their equivalents termed differently, but in the cases of some of them, the problem is not as crucial from the point of the quality of obtained appraisal results as it is in the case of SAREMA. A similar conceptual category is typically applied to mass real estate appraisal within the scope of socalled universal taxation, where it is usually termed as a taxation zone, while the concept of an elementary terrain itself derives from the terminology used for planning designs. The term of a zone is used in the Land Management Act in the section devoted to universal taxation, providing that: "in order to determine a cadastral value of land, unitary values of the land surface located in the zones are 
determined for the zones isolated on account of similar factors affecting their market value" (Article 166.1). In turn, secondary legislation to the act, namely an ordinance of the Council of Ministers on universal real estate taxation, speaks of taxation zones, which it defines on the basis of data analyses from a real estate cadastre, land and mortgage register, local zoning plan, data concerning transaction prices, rents and income from real estate, a basic map, geodetic records of the technical infrastructure network of the terrain and other documents (section 9 in conjunction with section 7). A list of taxation zones is supposed to constitute an integral part of a taxation map (section 10.2). The literature also mentions the problem of designating elementary terrains, or taxation zones, most often in the context of universal taxation (BECK 1975; PRZEWŁOCKI 1994 - ed.; KOWALSKI 1994A; BROWN, HEPWORTH 2001; BIRD, SLACK 2002; KOPYŚCIAŃSKA 2016; MIKA 2016), which ought to be considered as an official attribution of taxation values to real properties which will be used for determining tax amounts, and which may also be used for planning, economic, administrative and other purposes (KOWALSKI 1994b). Isolating taxation zones constitutes one of the basic steps in the procedure of universal real estate taxation. Taxation zones ought to be designated on the basis of the so-called real estate pricesetting qualities, the fundamental of which includes a function assigned in a zoning plan (SAwIŁOW 2009). The existing approaches to determining taxation zones, apart from techniques based on the provisions of local zoning plans, also comprise the use of aerial, satellite photographs as well as expert intervention in the boundaries of the terrains designated on the basis of those criteria (SUROWIEC, MALCZEWSKA 2001). Auxiliarly, district and housing estate boundaries, plot lines, streets, roads, rivers, railway routes and other artificial and natural features may be used for that purpose (DEDKOVA, POLYAKOVA 2018). In terms of the issues related to spatial planning, designated elementary terrains, understood as compact areas of the same planning function, may be linked with the value level of real properties covered by it in two ways. On the one hand, a real property function in a zoning plan as well as a real property location (it being a part of a particular elementary terrain) constitute a significant factor of a real property value, on the other hand, real property values may serve as the grounds for designating the boundaries of such a terrain (cf. KRAJEWSKA 1997; CYMERMAN 2000; CYMERMAN, GWIAŹDZIŃSKA, KUROWSKA 2001; CYMERMAN - ed. 2011). Postulates , apart from functional qualities of the terrains, the so-called physiognomic qualities, or even legal ones (real property ownership structure) also ought to be taken into account have also been put forward (KOTKOWSKI 1999). The concept of an elementary terrain employed in this paper is not fully equivalent to the term applied in spatial planning, where the concept refers to a fragment of a city terrain isolated in a plan drawing with boundary lines, for which detailed plan provisions are formulated; such a situation did however occur during the first applications of the algorithm, when the entire area of the city was covered by zoning plans. At present, when local zoning plans (be it in Szczecin or in a majority of municipalities in Poland) cover only specific fragments of a municipality, it is necessary to isolate elementary terrains on the grounds of other premises than only the functions stipulated in a zoning plan. Similarly, also the concept of an elementary terrain used in this article is not entirely equivalent to the concept of a taxation zone referred to in the Land Management Act as well as in the ordinance on universal real estate taxation. The legitimacy of applying mass real estate procedures as indicated above in least different areas requires a certain degree of versatility of the applied algorithm. Therefore, not wishing to introduce a completely new concept, the term of an elementary terrain was maintained, however perceiving that concept, as mentioned above, in a slightly different manner than in the case of original concepts, i.e. the ones deriving from spatial planning.

Incorrect designation of taxation zones may have far-reaching consequences. There is a natural temptation to designate the smallest possible number of elementary terrains, since it is easier to operate on less numerous data sets and fewer real properties will need to be appraised individually as representatives. The effect of designating an insufficient number of elementary terrains and, consequently, too expansive zones, will result in qualifying distinctly different real properties in terms of market location attractiveness as real properties featuring the same location attractiveness, which will naturally affect appraisal results with excessive errors. In turn, if too many elementary terrains are formed, thereby terrains of a relatively small surface, we might not be undermining the results accuracy, but we unnecessarily lengthen the process and raise the cost of such an appraisal, since in such a situation, more representative properties need to be valued individually. Moreover, a greater number of zones may be created, in which a few properties will be subject to evaluation, for instance one, two or three real properties. In such cases, the number of representative properties will constitute 
a very high percentage of all appraised real properties, at times rendering the point of mass appraisal questionable. Practical experience of the algorithm creators indicates that the following sampling selection ensures a suitable representativeness of a location, expressed in the algorithm as WWR (ed. HOZER 1999):

- from zones where up to 10 real properties are appraised - one representative real property,

- from zones where from 10 to 50 real properties are appraised - two representative real properties,

- from zones where from 51 to 100 real properties are appraised - three representative real properties,

- from zones where from 101 to 500 real properties are appraised - four representative real properties,

- from zones where from 501 to 1000 real properties are appraised - five representative real properties,

- from zones where over 1000 real properties are appraised - six representative real properties.

Another question that needs to be resolved when designating elementary terrains is their objective scope. It has to be decided whether individual elementary terrains should include only real properties of a purpose similar or comparable in the light of Article 4.16 of the Land Management Act, or whether we should allow the possibility of real properties of different purposes located in one elementary terrain. The consequence of adopting the first option will be the need for the designation of numerous small elementary terrains, comprising a small number, or even individual real properties. This will be the case when, e.g. a commercial facility is erected at a housing estate, which is in fact a commonplace occurrence. In such circumstances, that property will constitute a separate elementary terrain. The consequence of adopting the second solution may also be varied, but in simple terms it may be brought down to the following situations:

1. for each of the isolated elementary terrains, we determine one $W W R$, while the manner of real estate use or designated purpose are treated as a quality that will be reflected in a set of attributes;

2. for each of the isolated elementary terrains, we determine as many $W W R^{\prime} s$ as there are manners of real estate use (designated purposes) in a given terrain;

3. we isolate separate elementary terrains for each of the manners of real estate use (purpose). The terrains will overlap, thereby creating layers. In that case, elementary terrains with an assigned manner of use (purpose) of e.g. "industry, bases, warehouses", being less sensitive to location, may encompass within their limits several elementary terrains assigned to the manner of use (purpose) of, e.g. "housing, garages, public purposes, recreation".

The adoption of any of the above-specified concepts has its own advantages and disadvantages. With regard to the first option, it must be noted that such a situation may be debatable in terms of the substantive correctness of an appraisal process. It is believed that the appraisal of a real property of a given purpose ought to be a derivative of real estate market transactions of the same or similar (comparable) designation, and not the transactions of the real estate with different plan provisions, brought down to the purpose of the appraised real property through suitable adjustments. The advantage it offers is clarity and simplicity. Consequently, we obtain as many WWR's as there are elementary terrains, and each $W W R$ refers to one elementary terrain.

The consequence of adopting the second concept will mean that each elementary terrain will be assigned with several WWR's - as many as there are purposes (manners of use) of a real estate in a given designated elementary terrain. This, in turn, entails the necessity of randomly selecting and individually appraising a greater number of representatives for each terrain, since each purpose must, in this case, have "its" representatives. The advantages of this option, when compared to the first one, include legal appropriateness, and in relation to the third concept - greater process transparency, since we do not deal with several different types of elementary terrains.

The third concept, although it may seem to be substantively the most appropriate, brings about certain risks and dangers. First of all, isolated elementary terrains, particularly those whose purposes occur relatively rarely, may turn out to be so extensive in terms of their area that reflecting the impact of the location on the value of individual real property located in different "corners" of such a large elementary terrain with one WWR will be so inaccurate that it will undermine the accuracy of the obtained appraisal results. Furthermore, the procedure of designating elementary terrains separately for individual real estate purposes itself causes a significant extension and greater labor intensity of 
the entire appraisal process. In this case, in reality, we deal with several, in a sense independent, mass appraisals.

Although each of the above-listed concepts of an approach to the designation of elementary terrains, assuming a suitable substantive supervision, may result in good appraisal results from the point of view of their accuracy, it must be decided on which them proper works on the designation of elementary terrain boundaries will be based prior to their commencement.

\section{Practical proposal for designating elementary terrains}

How then should elementary terrains be designated?

Within the scope of preparatory work, basic parameters of conducted mass real estate appraisal need to be identified, which ought to include:

- the number of real properties subject to appraisal,

- structure of real estate designated purposes (manners of use),

- real estate distribution (distribution in space).

In the example presented in this paper, the following qualification of real estate purpose (manner of use) was applied:

1. real estate designated or used chiefly as a greenbelt, for agricultural purposes, or similar and accompanying functions as well as when it constitutes inner city wasteland,

2. real estate designated or used chiefly for industrial purposes, operating bases, warehouses, vehicle maneuver and transport areas (including roads and pavements), locations of technical infrastructure facilities and accompanying functions,

3. appraised real estate is designated or used chiefly for residential, recreational, garage or public purposes, as well as accompanying functions,

4. appraised real estate is designated or used chiefly for commercial purposes, including retail, specialist or office services and accompanying functions.

Naturally, questions may arise regarding the justifiability of such qualifications and, in particular, regarding the combinations of some of them. There are two basic reasons justifying such combinations. First of all, in reality, individual types of purposes are closely intertwined. In particular, in such a way that e.g. public purposes (schools, doctors' offices, post offices, administrative residential estate, etc.) and recreational purposes (squares, small parks, playgrounds, etc.) typically accompany a residential function and jointly constitute a mosaic of sorts, but frequently the purposes are realized within one real estate. The creation of new elementary terrains particularly for these sorts of functions of relatively small areas, on the one hand, would destroy the idea of elementary terrains, while on the other hand, it would typically cause the need for designating elementary terrains for individual real estate. It is, in a way, a "technical" reason related to the nature of the adopted algorithm. Secondly, qualifying such functions in a common elementary terrain does not automatically mean that, as a result of appraisal, we will obtain a value of a real property of various functions at the same level. The fact that real properties of residential, public and recreational functions will be situated in one elementary terrain only proves that they are located in an "equally fashionable" part of the entire area in which an appraisal is carried out. This is not in contradiction to the correctness of an appraisal process, because if an appraisal encompassed the real properties located in the territory of, e.g., expansive parks, such a park would need to be considered as a separate elementary terrain.

In our example, 1739 land plots were subject to appraisal, whose purpose structure is presented in Table 1.

Table 1

Purpose structure of appraised real properties

\begin{tabular}{cc}
\hline Purpose & Number of real properties \\
\hline 1 & 5 \\
\hline 2 & 387 \\
\hline 3 & 1299 \\
\hline 4 & 48 \\
\hline
\end{tabular}

Source: own calculations. 
The appraised real properties are located in Region 3 - Nad Odrą of the city of Szczecin, in various surveying districts, some of them bordering, others not. These conditions were the reason why it was decided that the second of the discussed concepts of elementary terrains constructions would be chosen, i.e. designation of common elementary terrains for all the purposes, with various WWR's for different purposes.

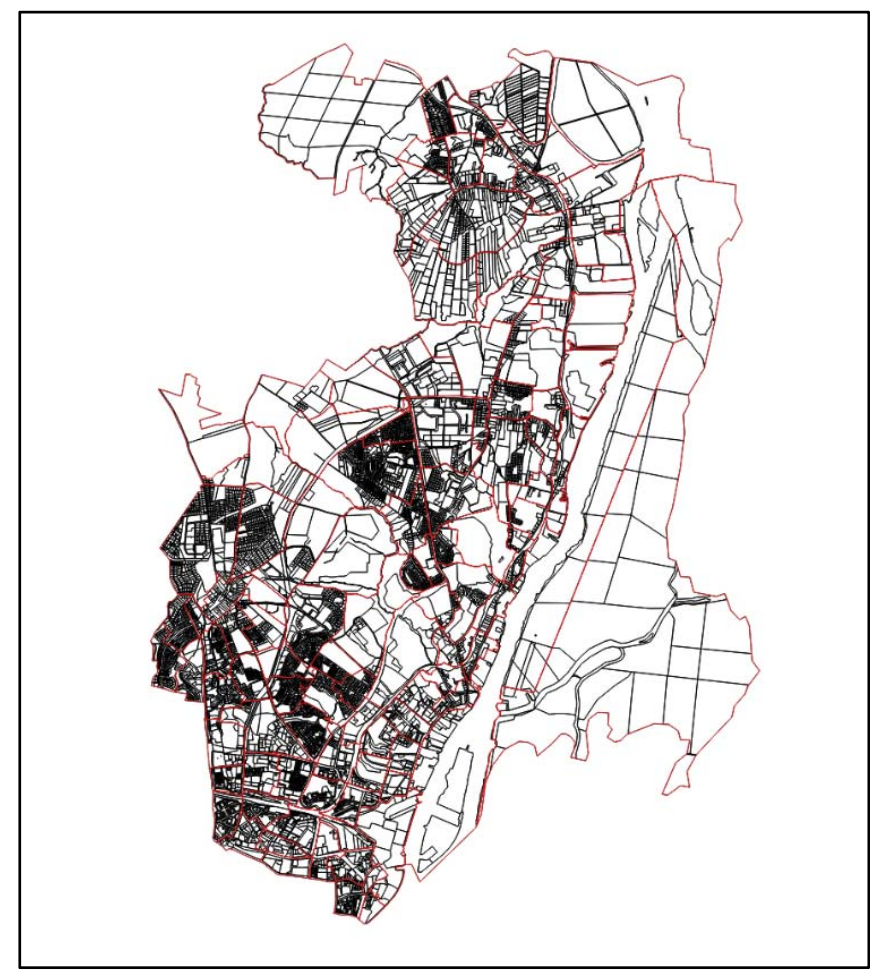

Fig. 1. Surveying structure (districts and plots) of Region 3 in Szczecin. Source: own elaboration.

When attempting to designate elementary terrains, it is good to have some preliminary division of the area in which the appraised real properties are located. Then the designation of elementary terrain boundaries can be carried out by analyzing the adequacy of such a division to the required elementary terrain boundaries. Such a preliminary division might be provided by a division into surveying districts, ranges of local zoning plans (or even plans still under preparation), or the terrains of the purposes established in those plans. Obviously, elementary terrains may also be designated "from scratch", i.e. without any preliminary division. Irrespectively of whether and what type of a preliminary division is at one's disposal, one needs to have orientation in the terrain; in other words, one has to know the topography of the area being appraised. Mass appraisal, independently of the method employed, ought to be conducted with the participation of the people who know the terrain. Publically available satellite photographs may prove to be helpful. In the presented example, two approaches will be used as a preliminary division:

- a division using surveying districts,

- a division based on statistical clustering methods.

Areas with valid local zoning plans or terrains with purposes designated in the plan could not be used, since local zoning plans do not provide full coverage of the city of Szczecin. In the case of Szczecin, surveying districts are well suited for that purpose since, in comparison to other cities, their surface is not large and there are relatively few of them. The limits of the surveying districts on a surveying districts map of Region 3 in Szczecin are presented in Fig. 1. Another option for a preliminary division of the appraised area into elementary terrains is the application of statistical clustering methods, thanks to which real properties similar in terms of specified qualities will be included in a common elementary terrain. Spatial clustering or their regionalization constitute important branches of science related to spatial analyses, while any references to them and their application can be found in various scientific studies (see, inter alia LAWSON, DENISON 2002, CARVALHO et al. 2009). 
From the point of view of elementary terrain formulation for the purpose of the SAREMA, apart from uniform location evaluation, the variation of the designated areas of appraised real properties on account of other market qualities ought to be relatively low. Such a situation will cause the differentiation of the values of randomly selected representatives to be lower, and this in turn will result in calculated WWR's being less sensitive to a strong impact of the outlying or atypical values.

In order to analyze how real properties differ in initial stages of elementary terrain formulation in terms of the specified market qualities, a measure of entropy was used (DosZYŃ 2008):

$$
H=-\sum_{i=1}^{k} p_{i} \log _{k} p_{i},
$$

where:

$p_{i} \quad$ - share or a real property belonging to $i$-th class,

$k \quad-$ number of classes.

Real property classes were created on account of three market qualities:

- technical infrastructure,

- neighborhood,

- available means of transport.

The percentage share of the number of real properties of the same variants of the above qualities in the sum total of all real properties in a given elementary terrain created $p_{i}$ values. The sum of the possible combinations of market quality variants created a $k$ value. Measure (5) is within the range of $\langle 0,1\rangle .0$ values are reserved for such elementary terrains in which all the real properties have the same variants of the stipulated market qualities. The entry measure will assume the value of 1 only in the situation when each real property in an elementary terrain will have a different (characteristic only for itself) combination of market quality variants.

As previously mentioned, the problem of the division of an appraised area into elementary terrains is related to the necessary compromise between their number, complications related with the appraisal of representative properties and ensuring a proper grasping of the impact of location on the value of appraised real properties. In other words: elementary terrains cannot be too numerous or too few. In Figure 2, a distribution of an original division of elementary terrains was present based on surveying districts on account of the number of appraised real properties in individual districts.

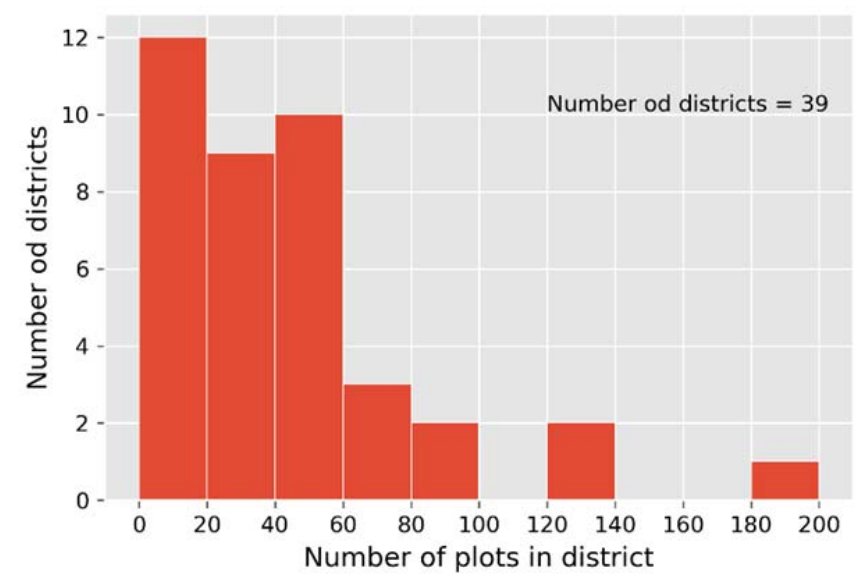

Fig. 2. Distribution of the number of plots. Source: own elaboration.

There are 39 surveying districts in the analyzed set of real properties. The majority of them contain up to 40 real properties subject to appraisal. There are only a few districts with a large number of real properties. Such a structure of the terrains requires, according to previously described guidelines, approximately 90 representatives for individual appraisal.

In Figure 3 a distribution of entropy for individual districts is presented.

A large group, as many as 10 districts, has very low entropy, which means that real properties located in them in their entirety or in a vast majority have the same variants of market qualities. Average entropy level for the division of elementary terrains based on districts is equal to 0.533 . 


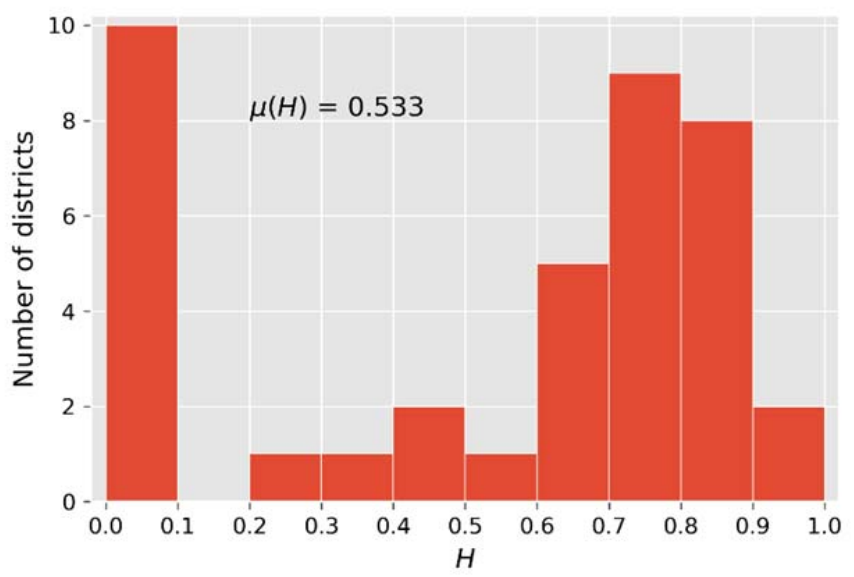

Fig. 3. Distribution of real property entropy in individual districts. Source: own elaboration.

The second way of carrying out original assignment of appraised real properties to elementary terrains is based on hierarchical spatial clustering. The functioning of the method requires specifying a distance or adjacency matrix for the appraised properties. The matrices may be created in a number of ways. One of the matrices divisions can be found in the work of (GETIS, ALDSTADT 2004, pp. 147-163). The division contains, inter alia:

- adjacency matrices,

- matrices of $k$ nearest neighbors,

- matrices of reverse distance,

- matrices of reverse distance with a limitation to $k$ nearest neighbors,

- matrices in which $i$ and $j$ are neighbors, if the distance between them is smaller or equal to a predetermined value.

One frequently used variant of a distance matrix is the last listed variant, in which a determined distance is chosen so that each of the objects has at least one adjacent object (the so-called lack of islands). It is precisely this variant of a distance matrix that was tested in this study. Real properties are qualified into this $i$-th elementary terrain if they have the same or similar variants of market qualities and they are neighbors according to the applied distance matrix.

For the purpose of this study, spatial clustering conducted with a Ward method was proposed taking into account the above-described distance matrix. The key aspect of the clustering methods is defining into how many groups (elementary terrains) the division should be made. It was found that a greater number of elementary terrains than arises from the division into districts will not be taken into consideration. On account of this fact, real estate clustering was conducted into a number of elementary terrains with the range of 2 to 39. A comparison of average entropy of those divisions in relation to the entropy of the division according to districts was presented in Figure 4.

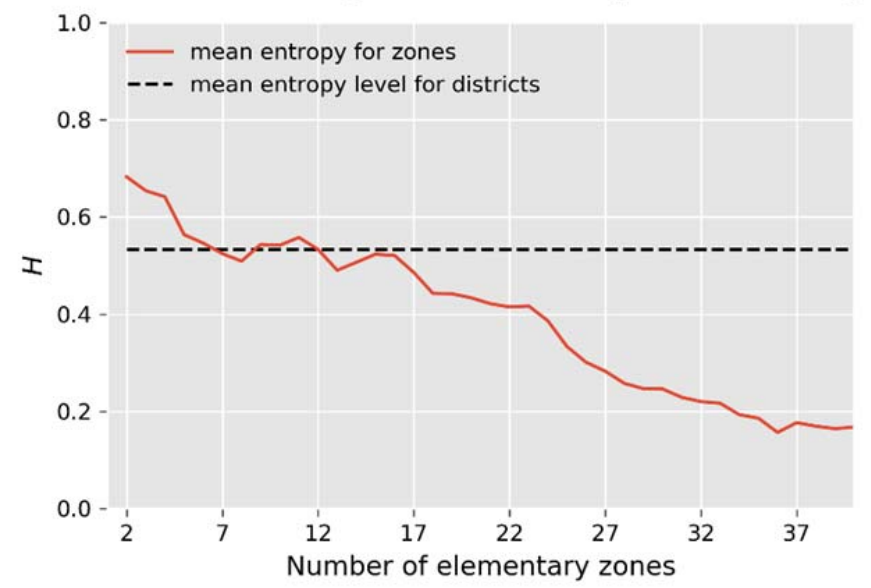

Fig. 4. Average entropy of elementary terrains for clustering of 2 to 39 terrains. Source: own elaboration. 


\section{$\$$ sciendo}

As can be observed in Figure 4, starting with already about 17 elementary terrains, average entropy for a division conducted with statistical methods is lower than for the classification of real properties based on them being part of individual districts. In the case of a number of terrains equal to the number of districts, average entropy is over twice as low ( 0.21 in relation to 0.53$)$. This raises hope that it is possible to carry out the division into a smaller number of terrains with lower entropy, which an exceptionally favorable perspective. Unfortunately, more detailed analyses demonstrate that agglomerative clustering cannot be recognized as the proper method in terms of the application of SAREMA. The idea of market value ratios is that they constitute an evaluation of the analyzed location attractiveness. For real properties found in the real estate data base (on account of the fact that the appraised area does not constitute a cohesive appraisal area) a distance matrix is used, within the scope of which the neighbors of the $i$-th real property are recognized as the ones that are equidistant from or within a distance that is less than the assumed radius. Such matrix specificity causes the created elementary terrains to encompass mutually overlapping areas. From the standpoint of the applied appraisal algorithm, this is an unacceptable situation. An example of such a situation is presented in Figure 5.

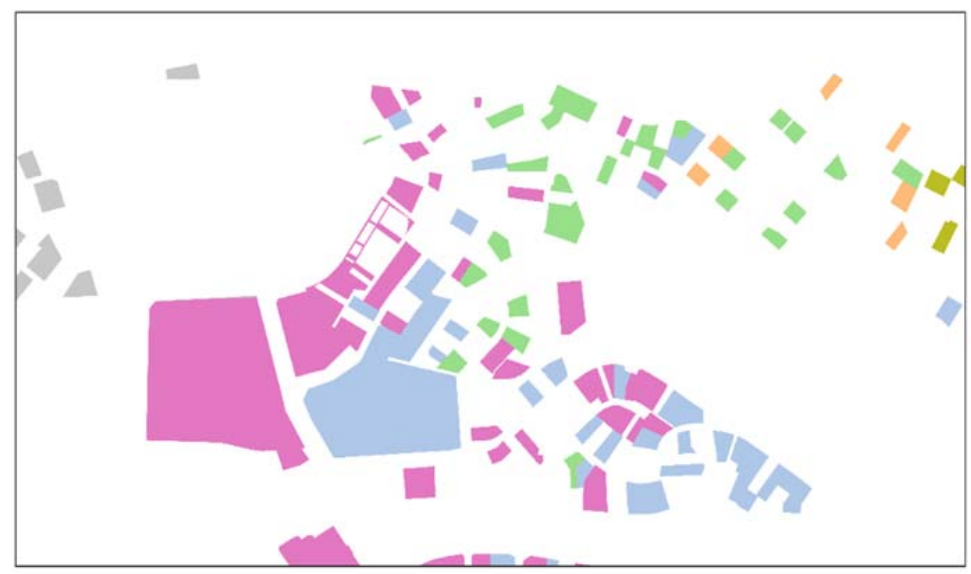

Fig. 5 Classification of real estate into elementary terrains with Ward method in a selected area (with a division into 17 elementary terrains). Source: Own elaboration.

Continuing the process of elementary terrain specification, after carrying out the evaluation of a division into districts and a statistical division, an expert analysis was conducted, both for the result of the two preliminary methods, as well as the market specificity of the appraised area, and a proper division was made using the results of preliminary methods as support. The result is a division of the appraised area into 17 elementary terrains (in correspondence with a statistical division, which enables achieving entropy at a higher level than division at the level of districts did). In turn, the terrain boundaries themselves had district limits as a starting point. During the work conducted, there were situations when one surveying district was qualified as one elementary terrain, one elementary terrain comprised one surveying district and a fragment of another district, one elementary terrain comprised several surveying districts, and where one elementary terrain constituted only a part of one surveying district. The final proposed division into elementary terrains as well as suitable examples are presented in Figures 6-9.

As a result, a structure of real estate purposes (manners of use) was obtained and presented in Table 2 .

Table 2

Structure of real estate purposes (manners of use)

\begin{tabular}{|c|c|c|c|c|c|c|c|}
\hline \multirow{2}{*}{$\begin{array}{c}\text { Elementary } \\
\text { terrain }\end{array}$} & \multicolumn{4}{|c|}{ purpose } & \multirow{2}{*}{ sum } & \multirow{2}{*}{$\begin{array}{c}\text { number of plots } \\
\text { in an } \\
\text { elementary } \\
\text { terrain } \\
\end{array}$} & \multirow{2}{*}{$\begin{array}{c}\text { Percentage } \\
\text { share of } \\
\text { appraised plots }\end{array}$} \\
\hline & 1 & 2 & 3 & 4 & & & \\
\hline 01 & & 9 & & & 9 & 113 & $8 \%$ \\
\hline
\end{tabular}




\section{sciendo}

\begin{tabular}{|c|c|c|c|c|c|c|c|}
\hline \multirow{2}{*}{$\begin{array}{c}\text { Elementary } \\
\text { terrain }\end{array}$} & \multicolumn{4}{|c|}{ purpose } & \multirow{2}{*}{ sum } & \multirow{2}{*}{$\begin{array}{c}\text { number of plots } \\
\text { in an } \\
\text { elementary } \\
\text { terrain }\end{array}$} & \multirow{2}{*}{$\begin{array}{c}\text { Percentage } \\
\text { share of } \\
\text { appraised plots }\end{array}$} \\
\hline & 1 & 2 & 3 & 4 & & & \\
\hline 02 & & & 3 & & 3 & 332 & $1 \%$ \\
\hline 03 & & & 242 & 2 & 244 & 1259 & $19 \%$ \\
\hline 04 & & & 51 & & 51 & 482 & $11 \%$ \\
\hline 05 & & 13 & 178 & 2 & 193 & 762 & $25 \%$ \\
\hline 06 & & 1 & 62 & & 63 & 868 & $7 \%$ \\
\hline 07 & & 69 & 329 & 4 & 402 & 1289 & $31 \%$ \\
\hline 08 & 1 & 10 & 35 & 3 & 49 & 289 & $17 \%$ \\
\hline 09 & 1 & 47 & 95 & 11 & 154 & 388 & $40 \%$ \\
\hline 10 & & 21 & 35 & 7 & 63 & 196 & $32 \%$ \\
\hline 11 & & 19 & 50 & 1 & 70 & 318 & $22 \%$ \\
\hline 12 & 3 & 22 & 1 & & 26 & 298 & $9 \%$ \\
\hline 13 & & 82 & 42 & 3 & 127 & 315 & $40 \%$ \\
\hline 14 & & 78 & 43 & 4 & 125 & 603 & $21 \%$ \\
\hline 15 & & 14 & 126 & 2 & 142 & 424 & $33 \%$ \\
\hline 16 & & 1 & 7 & 9 & 17 & 84 & $20 \%$ \\
\hline 17 & & 1 & & & 1 & 36 & $3 \%$ \\
\hline sum & 5 & 387 & 1299 & 48 & 1739 & 8056 & $21 \%$ \\
\hline
\end{tabular}

Source: own calculation

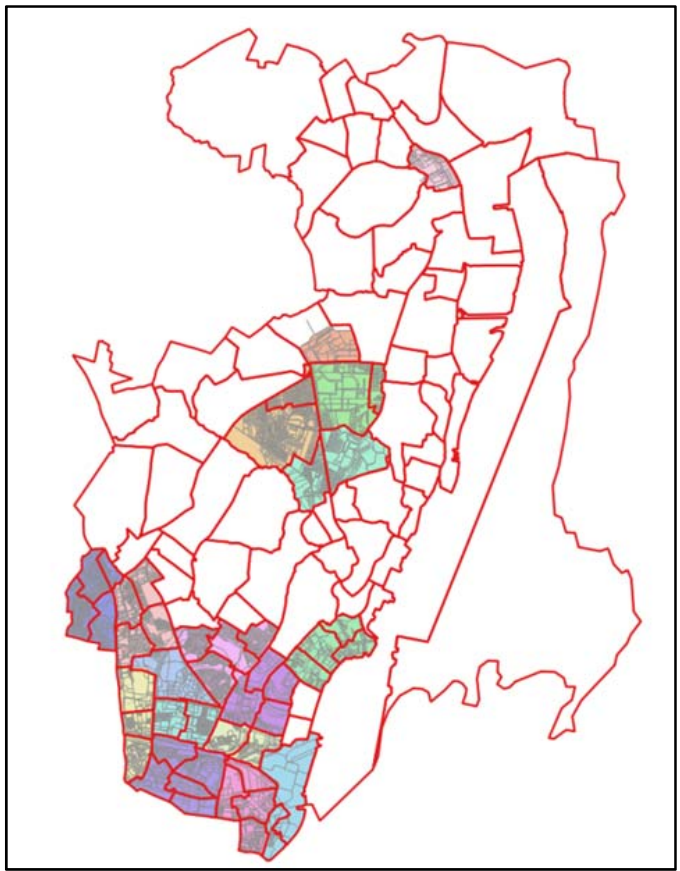

Fig. 6. Elementary terrains designated for the purpose of the appraisal. Source: own elaboration. 


\section{S sciendo}

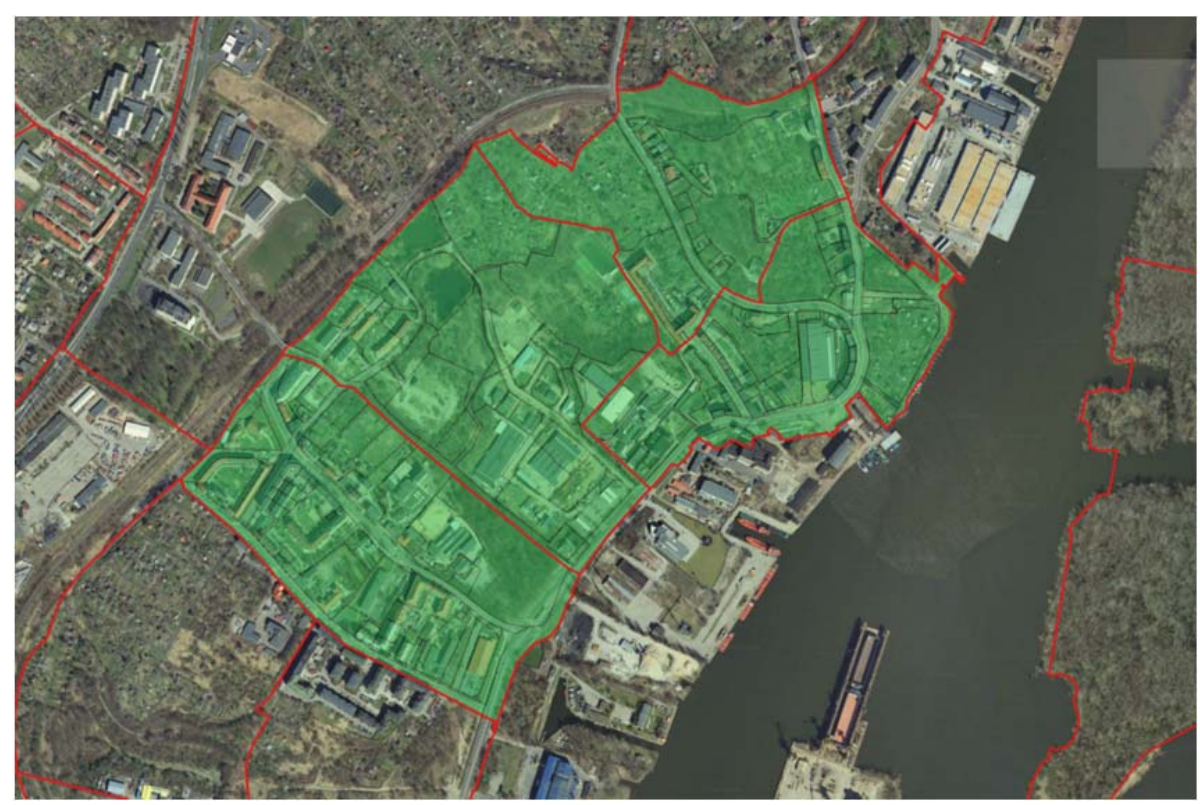

Fig. 7. Elementary terrain comprised of several surveying districts. Source: own elaboration.

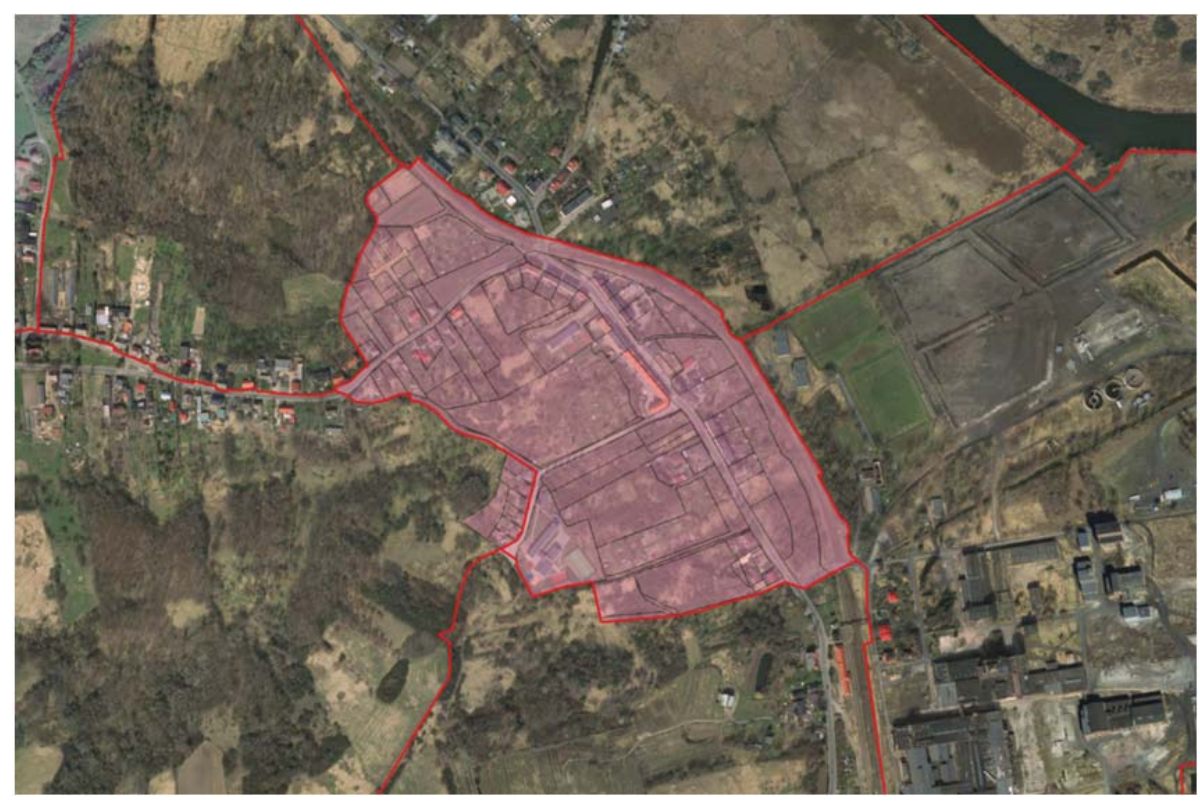

Fig. 8. Elementary terrain comprised of one surveying district and a small area outside of that district. Source: own elaboration.

It appears that the structure of real estate purposes (manners of use) in elementary terrains is widely varied. In Terrain 17, there is one real property that is subject to appraisal. In practice, this will mean that it is going to be appraised individually. There are also terrains of a relatively large number of real properties intended for appraisal (e.g. 01, 02, 16, 12). However, there are also relatively numerous terrains - the most numerous one (Terrain 07) has over 400 appraised real properties. Four elementary terrains $(01,02,04$ and 17$)$ have real properties intended for appraisal only of one purpose (manner of use). Only two elementary terrains (08 and 09) feature real properties of all four types of assigned purposes.

When designating elementary terrains, it is worth considering whether a conducted mass appraisal is a one-off procedure, or whether the team carrying it out foresees that it will be periodically repeated. A one-off appraisal may be found to be useful in particular when evaluating the economic results of an amendment of local zoning plans. Periodically repeated appraisals may concern updating 
annual perpetual usufruct charges, monitoring the value of real estate sets constituting a security of loan exposures held by banks, or in the long term, universal real estate taxation. If an appraisal is to have a periodic character, elementary terrains may be designated outside of the area of a direct location of the appraised real estate. Similarly, elementary terrain boundaries can be extended in such a way that the terrains would constitute references of potential location characteristics, and not only directly the areas of the appraised real estate location.

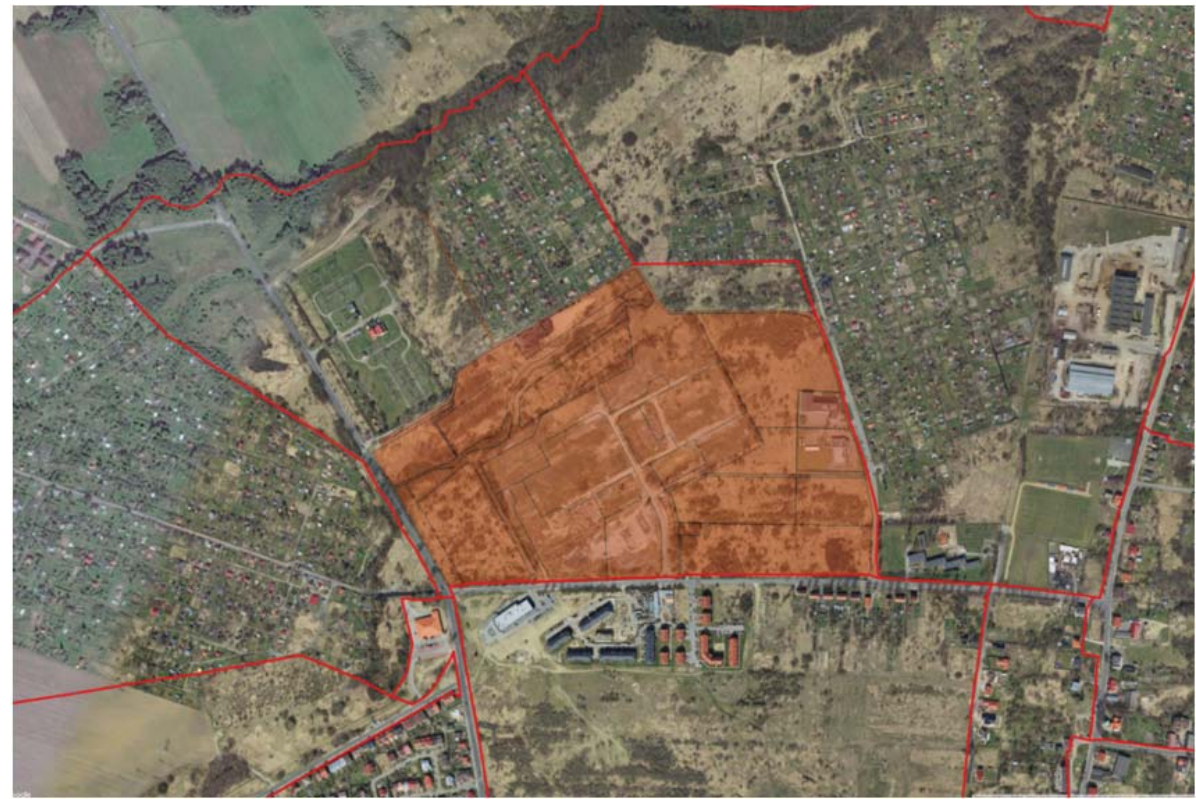

Fig. 9. Elementary terrain covering a part of one surveying district. Source: own elaboration.

\section{Discussion and conclusions}

The problems of specifying elementary terrains for mass appraisal were presented in the article, and in this particular case, with the use of the Szczecin Real Estate Mass Appraisal Algorithm. The article raised the issues related to expectations regarding qualifying the appraised real properties into individual elementary terrains. The article focused on the need to ensure a uniform impact of a location on the value of the appraisal of elementary terrains, as well as on the desirable small variety of the real properties found within elementary terrains on account of the specified qualities. As a result of the conducted research, it was found that automated methods may constitute only a preliminary stage before the proper division conducted by experts takes place. A division based on surveying districts offers the advantage of having already been completed. However, with a given real estate data base intended for appraisal, it showed a large number of terrains containing few real properties, which caused the need for randomly selecting multiple representatives (since, according to SAREMA, a real property must be randomly selected from each elementary terrain for individual appraisal). A large number of representative properties results in longer duration of the appraisal process and increases the cost of its completion. In turn, the method of statistical clustering resulted in the creation of "overlapping" elementary terrains, which stands in contradiction to the nature of determining market value ratios. Furthermore, a disadvantage of hierarchical clustering is that, with this method, terrain boundaries are not designated. Clustering classifies only the real properties subject to appraisal into a pre-determined number of clusters. This method does not allow us to demonstrate that real properties other than the ones that were subject to clustering belong to any terrain. Clustering methods with spatial limitations appear to be more effective in the situations when the entire areas are subject to clustering (see WU, SHARMA 2012) and not, as in this case, their various fragments. On that account, an expert division preceded by preliminary stages was deemed to be the optimum division of elementary terrains. An expert division enables the spotting of specific characteristics of a local real property market, the finding of which would be impossible or highly complicated in an automated method. It involves, for instance, individual occurrence in the appraised territory of natural or artificial objects that affect a local real estate market. Further studies in this 


\section{$\$$ sciendo}

respect will concern the influence of an adopted distance matrix on the classification of a real property and attempts at developing a measure of optimal entropy and the number of elementary terrains.

\section{Acknowledgement}

The research was conducted within the project financed by the National Science Centre, Project No 2017/25/B/HS4/01813.

\section{References}

ADAIR, A. S., BERRY J. N., MCGREAL W. S., 1996, Hedonic modelling, housing submarkets and residential valuation, Journal of Property Research, no. 13(1), pp 67-83.

BRADBURY K.L., MAYER CH.J., CASE K.E., 2001, Property tax limits, local fiscal behavior, and property values: evidence from Massachusetts under Proposition 2,5, Journal of Public Economics no. 80, pp. 287-311.

BECK W., 1975, Production of cadastral maps for rural and urban areas, World Cartography, no. 13.

BIRD M., SLACK E., 2002, Land and property taxation around the world: a review, Journal of property tax assessment and administration: an international journal, no. 7, pp. 31-80.

BOURASSA S. C., HAMELINK F., HOESLI M., MACGREGOR B. D., 1999, Defining Housing Submarkets, Journal of Housing Economics, no. 8(2), pp. 160-183.

BROWN P.K., HEPWORTH M.A., 2001, Study of European Land Tax Systems, Cambridge.

CARVALHO A.X.Y, ALBUQUERQUE P.H.M, DE ALMEIDA JUNIOR G.R., GUIMARÃES R.D., 2009, Spatial Hierarchical Clustering, Rev. Bras. Biom., São Paulo, no. 27(3), p.412-443.

CELlMER R., KURYJ J., 2011, Określanie stref o podobnej cenności gruntów z wykorzystaniem metod geostatystycznych (Designation of the zones of similar land value with the use of geostatistical methods) [in Polish], Studia i Materiały Towarzystwa Naukowego Nieruchomości, no. 19(3), pp. 7-18.

Cho, M, Megbolugbe I.F., 1996, An Empirical Analysis of Property Appraisal and Mortgage Redlining, Journal of Real Estate Finance and Economics, no. 13, pp. 45-55.

CYMERMAN R., 2000, Wartość planistyczna jako wskaźnik w planowaniu przestrzennym (Planning value as an indicator in spatial planning) [in Polish], Materiały konferencyjne VIII Konferencji Naukowej towarzystwa naukowego Nieruchomości, „Koncepcje wartości w teorii i praktyce wyceny nieruchomości", Olsztyn.

Cymerman R. (ed.), 2011, Planowanie przestrzenne dla rzeczoznawców majątkowych, zarządów oraz pośredników w obrocie nieruchomościami (Spatial planning for property appraisers, managers and real estate agents) [in Polish], Wyd. Educaterra, Olsztyn.

CYMERMAN R., GWIAŹDZIŃSKA M, KUROWSKA K., 2001, Wartość rynkowa nieruchomości jako kryterium wyboru funkcji terenu (Market value of real estate as a criterion for selecting the function of the land) [in Polish], I Konferencja Naukowo-Techniczna PSRWN „Współdziałanie rzeczoznawców majątkowych, urbanistów i gmin w procesie sporządzania i realizacji opracowań planistycznych". Gdańsk.

DedKova O., PolyaKova I., 2018, Development of Mass Valuation in Republic of Belarus, Geomatics and Environmental Engineering. no. 12(3), pp. 29-39.

DoszyŃ M., 2008, Statystyczno-ekonometryczna analiza skłonności ludzkich (Statistical-econometric analysis of human propensities) [in Polish], WNUS, Szczecin.

DosZYŃ M., 2012, Ekonometryczna wycena nieruchomości (Econometric property valuation) [in Polish], Studia i Prace Wydziału Nauk Ekonomicznych i Zarządzania, no. 26, Szczecin.

GALSTER C., 1996, William Grigsby and the analysis of housing submarkets and filtering, Urban Studies, no. 33(10), pp. 1797-1805.

GĄGOlewSKi M., BARTOSzUK M., CENA A., 2016, Przetwarzanie $i$ analiza danych w jezyku Python (Wrangling and analysis of data in Python) [in Polish], PWN, Warszawa.

GETIS A., ALDSTADT J., 2004, Constructing the Spatial Weights Matrix Using a Local Statistic, Geographical Analysis, no. 36(2), pp. 90-104.

HOZER J., 2001, Regresja wieloraka a wycena nieruchomości (Multiple regression and property valuation) [in Polish], Rzeczoznawca Majątkowy nr 2.

HOzER J., 1999, Wykorzystanie wyników analiz statystycznych rynku nieruchomości do szacowania nieruchomości (Using the results of statistical analyses of the real estate market for property valuation) [in Polish], Zesz. Nauk. Uniw. Szczecińskiego, no. 233, pp.173-186.

Hozer J. (ed.)., 1996, Statystyka (Statistics) [in Polish], Uniwersytet Szczeciński, Szczecin. 
Hozer J. (ed.)., 2008, Wycena Nieruchomości (Real Estate Valuation) [in Polish], KEiS US, IADiPG w Szczecinie, Szczecin.

HOzer J., КОКОт S., 2005, Problemy powszechnej taksacji nieruchomości w Polsce (Problems of general real estate taxation in Poland) [in Polish], Zeszyty Naukowe Uniwersytetu Szczecińskiego, no. 415, Uniwersytet Szczeciński, Szczecin.

HOZER J., KOKOT S., FORYŚ I., ZWOLANKOWSKA M., KUŹMIŃSKI W., 1999, Ekonometryczny algorytm masowej wyceny nieruchomości gruntowych (Econometric algorithm of mass land real estate appraisal) [in Polish], Uniwersytet Szczeciński, Stowarzyszenie Pomoc i Rozwój. Szczecin.

HOZER J., KOKOT S., KUŹMIŃSKI W., 2002, Metody analizy statystycznej rynku w wycenie nieruchomości (Methods of statistical analysis of the market in real estate appraisal) [in Polish], PFSRM, Warszawa.

IWAŃCZAK B., 2016, QGIS 2.14.3. Tworzenie i analiza map (QGIS 2.14.3. Map creation and analysis) [in Polish], Helion, Gliwice.

JAHANSHIRI E., BuYONG T., SHARIFF A.R.M., 2011, A review of Property Mass Valuation Models, Pertanika Journal of Science \& Technology, no. 19, pp. 23-30.

KESKIN B., WATKINS C., 2016., Defining spatial housing submarkets: Exploring the case for expert delineated boundaries, Urban Studies, no. 54(6), pp. 1446-1462.

KОКОт S., 2006, Model wielu regresji pojedynczych w wycenie nieruchomości (Multiple single regressions model in property valuation) [in Polish], Studia i Materiały Towarzystwa Naukowego Nieruchomości, no. 12(1), pp. 106-122.

KOT S.M., JAKUbOWSKI J., SOKOŁOWSKI A., 2007, Statystyka (Statistics) [in Polish], Wyd. Difin. Warszawa.

KOWALSKI G., 1994a, Rola i miejsce stref taksacyjnych w modelu powszechnej taksacji nieruchomości na obszarach zurbanizowanych (The role and place of tax zones in the model of general taxation of real estate in urban areas) [in Polish], in „Model ustalania i weryfikacji zasięgu stref taksacyjnych dla potrzeb powszechnej taksacji nieruchomości cz.I." Rzewłocki - red. Łódź, Wydawnictwo Politechniki Łódzkiej.

KOWALSKI G., 1994b, Powszechna taksacja nieruchomości w świetle teorii taksacji (General real estate taxation in the light of the tax theory) [in Polish]. Przegląd Geodezyjny nr 10.

KOPYŚCIAŃSKA K., 2016, Koncepcja podatku katastralnego w Polsce na tle doświadczeń wybranych krajów (The concept of cadastral tax in Poland against the background of experiences of selected countries) [in Polish], Prawnicza i Ekonomiczna Biblioteka Cyfrowa, Wrocław.

KORTEWEG A., SORENSEN M., 2016, Estimating Loan-to-Value Distributions. Real Estate Economics, no. 44(1), pp. 41-86.

KOTKOWSKI P., 1999, Propozycja nowej klasyfikacji terenów miejskich (Proposal for a new classification of urban areas) [in Polish]. Acta Universitatis Lodziensis, Folia Geographica Socio-Oeconomica 2. Wydawnictwo Uniwersytetu Łódzkiego. Łódź.

KURYJ J., 2007, Metodyka wyceny masowej nieruchomości na bazie aktualnych przepisów prawnych (Methodology of mass valuation of real estate on the basis of current legal regulations) [in Polish], Wycena no. 4(81), Educaterra, Olsztyn.

KRAJEWSKA M., 1997, Wartość nieruchomości jako regulator przy opracowywaniu miejscowego planu zagospodarowania przestrzennego (The property value as a regulator in the preparation of the local zoning plan) [in Polish], Materiały konferencyjne, V Konferencja Naukowa Towarzystwa Naukowego Nieruchomości „Rynek nieruchomości - zagospodarowanie przestrzenne”. Spała.

KRAWCZYK M., 2009, Powszechna taksacja nieruchomości - istota i znaczenie (General property taxation essence and significance) [in Polish], Ruch prawniczy, ekonomiczny i socjologiczny, ROK LXXI zeszyt 3.

LAWsON A.B., Denison D.G.T., 2002, Spatial Cluster Modelling, Chapman\&Hall CRC, Boca Raton, London, New York, Washington D.C.

MIKA M., 2016, Implementacja europejskich trendów podatku katastralnego w warunkach polskich (Implementation of European Cadastral Tax Trends in Polish Conditions) [in Polish], Acta Scientiarum Polonorum Administratio Locorum, no. 15(4), pp. 99-110.

PALM R., 1978, Spatial segmentation of the urban housing market, Economic Geography, no. 54, pp. 210221.

PAWLUKOWICZ R., 2001, Przegląd propozycji określania wartości rynkowej nieruchomości z wykorzystaniem modeli ekonometrycznych (Review of proposals for determining the market value of real estate using econometric models) [in Polish], Zeszyty Naukowe U.S., Szczecin. 
Peng L., Thibodeau T., 2013, Risk segmentation of American homes: The case of Denver, Real Estate Economics, no. 41(3), pp. 569-599.

PRYCE G., 2013, Housing Submarkets and the Lattice of Substitution, Urban Studies, no. 50(13), pp. 26822699.

PRYSTUPA M., 2000, O potrzebie dalszych prac nad zastosowaniem regresji wielorakiej w wycenie nieruchomości (On the need for further work on the application of multiple regression in property valuation) [in Polish], Rzeczoznawca Majątkowy, no. 4.

PRZEWŁOCKI S. (ed.), 1994, Model ustalania i weryfikacji zasieggu stref taksacyjnych dla potrzeb powszechnej taksacji nieruchomości (Model of determining and verifying the range of tax zones for the purposes of general property taxation) [in Polish], Wydawnictwo Politechniki Łódzkiej, Łódź.

RAE A., 2015, Online housing search and the geography of submarkets, Housing Studies, no. 30, pp. 453472.

Rozporządzenie Rady Ministrów z dnia 29 czerwca 2005 r. w sprawie powszechnej taksacji nieruchomości (Dz.U. Nr 131, poz. 1092).

Rosen S., 1974, Hedonic Prices and Implicit Markets: Product Differentiation in Pure Competition, Journal of Political Economy, no. 82(1), pp. 34-55.

SAWIŁOW E., 2009, Analiza wybranych metod modelowania wartości katastralnych nieruchomości, Acta Scientiarum Polonorum Geodesia et Descriptio Terrarum, no. 8(2), pp. 27-38.

SAWIŁOW E., AKIŃCZA M., 2011, Zastosowanie teorii modelowania dla potrzeb powszechnej taksacji nieruchomości (Analysis of selected methods of modelling cadastral values of real estate) [in Polish], Infrastruktura i Ekologia Terenów Wiejskich, no. 4, pp. 129-140.

SUCHECKI B. (ed.), 2010, Ekonometria przestrzenna. Metody i modele analizy danych przestrzennych (Spatial econometrics. Methods and models of spatial data analysis) [in Polish], Warszawa C.H. Beck.

SUROWIEC G., MALCZEWSKA A., 2001, Automatyzacja procesu wyodrębniania stref izowartościowych nieruchomości w oparciu o zdjęcia lotnicze (Automation of the process of isolating isovalue real estate zones based o aerial photographs) [in Polish], Archiwum Fotogrametrii, Kartografii i Teledetekcji, no. 11, Kraków.

TElegA T., BOJAR Z., ADAMCZEWSKI Z., 2002, Wytyczne przeprowadzenia powszechnej taksacji nieruchomości (Guidelines for the implementation of general real estate taxation) [in Polish], Przegląd Geodezyjny, no. 6, pp. 6-11.

TzIOUMIS K., 2017, Appraisers and Valuation Bias: An Empirical Analysis, Real Estate Economics, no. 45(3), pp. 679-712.

Ustawa z dnia 21 sierpnia 1997 r. o gospodarce nieruchomościami (Dz.U. 115 poz. 741 z późniejszymi zmianami) (Act of 21 August 1997 on Land Management, Journal of Laws, 1997, no. 115, item 741, as amended)

WU C., SHARMA R., 2012, Housing submarket classification: The role of spatial contiguity, Applied Geography, no. 32(2), pp. 746-756.

ZHU S., PACE R.K., 2012, Distressed Properties: Valuation Bias and Accuracy, Journal of Real Estate Finance and Economics no. 44, pp. 153-166.

ŹRÓBEK S., BEŁEJ M., 2000, Podejście porównawcze w szacowaniu nieruchomości (Comparative approach in real estate appraisal) [in Polish], Educaterra, Olsztyn. 